\title{
Correction to: Prokaryotic expression and action mechanism of antimicrobial LsGRP1C recombinant protein containing a fusion partner of small ubiquitin-like modifier
}

\author{
Chia-Hua Lin ${ }^{1} \cdot$ Ying-Chieh Pan $^{1} \cdot$ Fang-Wei Liu ${ }^{1}$ Chao-Ying Chen ${ }^{1}$
}

Published online: 22 November 2017

(C) Springer-Verlag GmbH Germany, part of Springer Nature 2017

Correction to: Appl Microbiol Biotechnol (2017) 101:8129-

8138

https://doi.org/10.1007/s00253-017-8530-z

The published online version contains editing mistake in

Table 2. See below for the corrected Table.

Table 2 The inhibitory activities of $E$. coli-expressed SUMO-LsGRP ${ }^{\mathrm{C}}$ and synthetic LsGRP ${ }^{\mathrm{C}}$ on fungal spore germination

$\mathrm{IC}_{50}$ of SUMO-LsGRP1 ${ }^{\mathrm{C}}$

$\mu \mathrm{g} / \mathrm{mL} \quad \mu \mathrm{M}$
$\mathrm{IC}_{50}$ of synthetic $\mathrm{LsGRP}^{\mathrm{C}}$

$\mu \mathrm{g} / \mathrm{mL}$

54.80

12.64

102.12

5.72

80.24

$\mu \mathrm{M}$

98.70

5.56

18.49
Fungal species $^{\mathrm{a}}$

Alternaria brassicicola Ac1

${ }^{\mathrm{a}}$ Inhibition of fungal spore germination $\left(5 \times 10^{4}\right.$ spores $\left./ \mathrm{ml}\right)$ was measured

The online version of the original article can be found under https://doi. org/10.1007/s00253-017-8530-z.

Chao-Ying Chen

cychen@ntu.edu.tw

1 Department of Plant Pathology and Microbiology, National Taiwan

University, No. 1, Sec. 4, Roosevelt Rd, Taipei 10617, Taiwan,

Republic of China 